Jakub JANIK ${ }^{1}$, Paweł FAŁAT ${ }^{2}$, Marta POMIETLORZ-LOSKA ${ }^{3}$, Robert DROBINA ${ }^{4}$

Opiekun naukowy: Robert Drobina ${ }^{4}$

DOI: https://doi.org/10.53052/9788366249868.08

\title{
ANALIZA PRZEDWDROŻENIOWA APLIKACJI MOBILNEJ MIERZĄCEJ PARAMETRY MEDYCZNE DLA EPILEPTYKÓW
}

Streszczenie: Praca bada potrzebę wdrożenia aplikacji mobilnej współpracującej $\mathrm{z}$ inteligentnym zegarkiem, która będzie mierzyła podstawowe parametry medyczne i aktywności sportowe. Zostało również przeprowadzone badanie rynku w celu zweryfikowania owego zapotrzebowania na daną funkcjonalność oraz rozwinięte pojęcie $\mathrm{z}$ zakresu elektrokardiografii serca.

Słowa kluczowe: analiza przedwdrożeniowa, aplikacja mobilna, parametry medyczne

\section{PRE-IMPLEMENTATION ANALYSIS OF MOBILE APPLICATION MEASURING MEDICAL PARAMETERS FOR EPILEPTICS}

Summary: The work examines the demand for the implementation of a mobile application working with a smart watch, which will measure basic medical parameters and sports activities. A market survey was also carried out to verify this demand for functionality and a developed concept in the field of cardiac electrocardiography.

Keywords: pre-implementation analysis, mobile application, medical parameters

\section{Wprowadzenie}

Obecnie coraz szybszy rozwój technologiczny poszerza horyzonty w zakresie diagnostyki oraz medycyny. Miniaturyzacja elektroniki w tym zakresie pozwala na wykonywanie długotrwałych badań podczas codziennych czynności. W wyniku owego procesu powstają narzędzia umożliwiające pomiar tętna, badanie EKG oraz aktywności sportowych. Nawet obecny rozwój cywilizacyjny nie jest w stanie wygrać

${ }^{1}$ Uniwersytet Jagielloński: janik1jakub@gmail.com

${ }^{2}$ Akademia Techniczno-Humanistyczna w Bielsku-Białej: pfalat@ath.bielsko.pl

${ }^{3}$ Akademia Techniczno-Humanistyczna w Bielsku-Białej: mpomietlorz@ath.bielsko.pl

${ }^{4}$ prof. ATH dr hab. inż., Akademia Techniczno-Humanistyczna w Bielsku-Białej:

rdrobina@ath.bielsko.pl 
z wieloma chorobami wraz $\mathrm{z}$ ich dolegliwościami. Chcąc wspomóc ludzi w diagnostyce oraz adaptacji zostanie przeprowadzone badanie rynku mające na celu sprawdzić zapotrzebowanie wdrożenia aplikacji mobilnej na rynku z wykorzystaniem smartwatcha.

\section{Badanie rynku}

W celu pełnego zweryfikowania funkcjonalności aplikacji i jej optymalizacji została przeprowadzona ankieta stworzona w Microsoft Forms [1]. Jest to narzędzie stworzone przez firmę Microsoft w 2016r. pozwalające tworzyć ankiety oraz quizy. Zebrane dane można wyeksportować do Programu Microsoft Excel [2]. Formularz został podzielony na cztery główne sekcje:

- Pytania ogólne

- Aplikacja desktopowa

- Aplikacja na telefon/smartwatch

- Podsumowanie

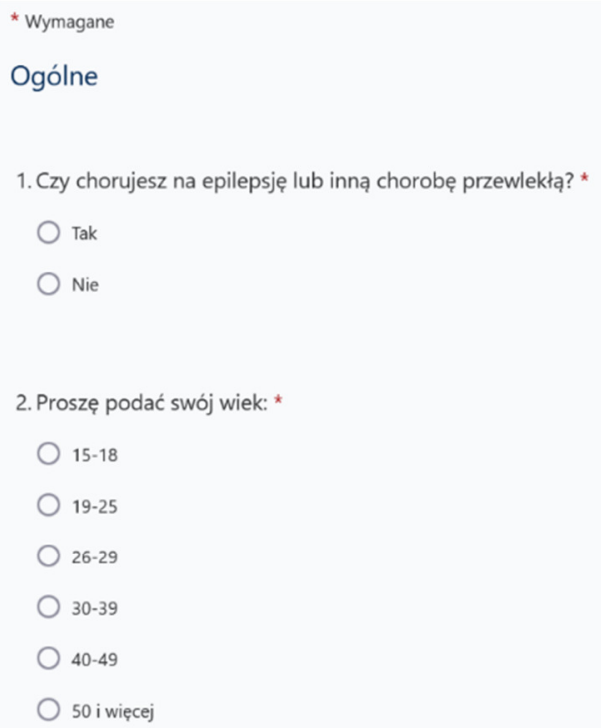


Dla niniejszego projektu podczas analizy danych zebranych od ankietowanych została pominięta część dotycząca aplikacji desktopowej. Badanie zostało przeprowadzone na około 120 osobach w różnych przedziale wiekowym w formie online, a ankieta trafiła na fora internetowe o tematyce zdrowotnej oraz chorobach przewlekłych.

W sekcji pierwszej zawarte zostały pytanie dotyczące styczności ankietowanych $\mathrm{z}$ epilepsją oraz wiek, co pozwoli na określenie w jakim przedziale wiekowym osoby stykają się z daną problematyką oraz w jakim stopniu ich dotyczy. Sekcja dotycząca aplikacji na telefon/smartwatch zawiera pytania dotyczące funkcjonalności aplikacji mobilnej przy jednoczesnym połączeniu z inteligentnym zegarkiem. Podczas analizy tej sekcji będzie można uzyskać liczbę osób użytkujących dedykowane aplikacje zdrowotne wraz $\mathrm{z}$ potrzebną funkcjonalnością zawartą w projekcie.

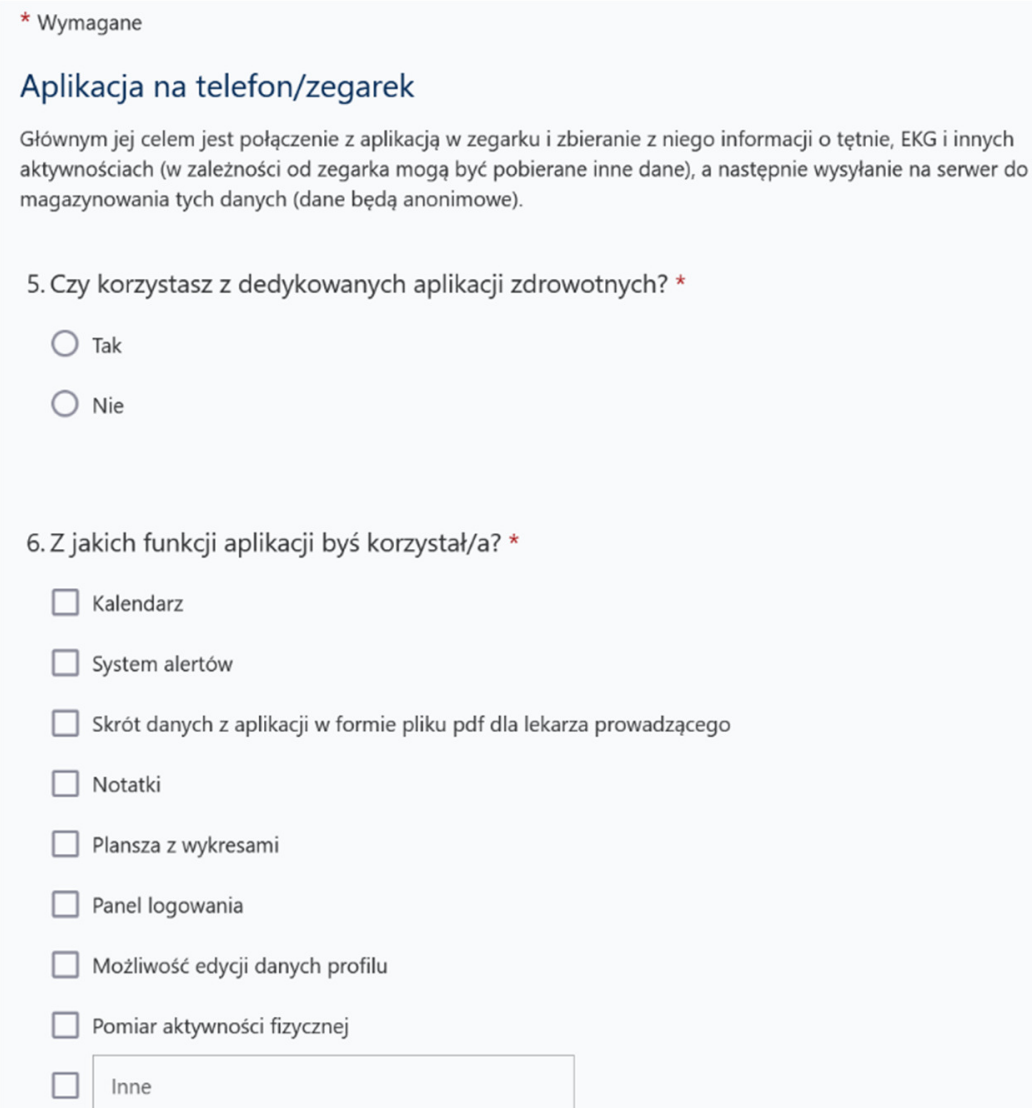


7. Czy korzystałbyś/abyś z dodatkowych funkcji aplikacji w zegarku? *
Tak
Nie

8. Jeśli tak, to $\mathrm{z}$ jakich?

Plansza z wykresami

Pomiar aktywności sportowej

Powiadomienia

Kalendarz

System alertów

Inne

Wstecz

Dalej

Strona 3 z 4

Rysunek 3. Ankieta - aplikacja na telefon/zegarek cd. [1]

Ostatnia sekcja badania zawiera pytania dotyczące dodatkowych sugestii na potrzeby stworzenia takowego projektu. Ostatni punkt zawiera chęć użytkowania aplikacji w sposób jawny lub anonimowy, co pozwoli na określenie ilości zbieranych danych.

Podsumowanie

9. Co sądzisz o takiej aplikacji? Czy taka aplikacji i zebrane z niej dane pomogły by w wcześniejszym wykrywaniu ataków epilepsji?

Wprowadź odpowiedź

10. Korzystałbyś/abyś z aplikacji jako użytkownik anonimy czy jawny (wiek, masa ciała, wzrost, imię, nazwisko)

anonimowy

jawny

Wstecz

Prześlij

Strona $4 \mathrm{z} 4$

Rysunek 4. Ankieta - podsumowanie [1] 
Na załączonych poniżej wynikach, które dotyczą pytania pierwszego oraz trzeciego z sekcji pierwszej można dostrzec, iż zdecydowana większość badanych choruje na epilepsją (82\%) lub zna ze swojego otoczenia osoby zmagające się z chorobami przewlekłymi $(70 \%)$. Na tej podstawie można założyć, że ankietowani posiadają minimum podstawowej wiedzy dotyczącej padaczki, a dalsze odpowiedzi dotyczące potrzebnych funkcjonalności będą wiarygodne.

1. Czy chorujesz na epilepsję lub inną chorobę przewlekłą? Więcej szczegółór Insights

$\begin{array}{ll}\text { Tak } & 100 \\ \text { Nie } & 22\end{array}$

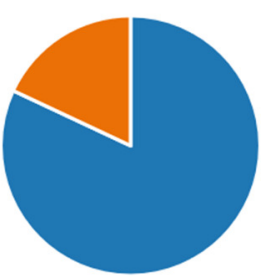

Rysunek 5. Wyniki badania - ilość chorujących wśród ankietowanych [1]

3. Czy posiadasz kogoś bliskiego/znajomego, który jest chory na epilepsję lub inną chorobę przewlekłą?

Więcej szczegółó Pig Insights

$\begin{array}{ll}\text { Tak } & 85 \\ \text { Nie } & 37\end{array}$

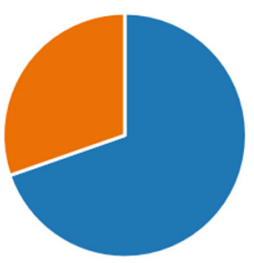

Rysunek 6. Wyniki badania - choroby przewlekłe wśród rówieśników [1]

Uwagę warto zwrócić na pytanie o wiek ankietowanych. Na 122 badanych, aż 48 to osoby znajdujące się w przedziale 19-25 lat, a aż stu czterech jest w przedziale 19-39 (Rysunek 7). Wynika z tego, iż ciężko wejść osobom starszym w dość obszerny świat technologii, co wskazuje zapotrzebowanie na prostotę obsługi aplikacji. Z drugiej jednak strony należy zauważyć, że w coraz większym stopniu choroby przewlekłe dotykają ludzi młodych. 
2. Proszę podać swój wiek:

Więcej szczegótów

\begin{tabular}{ll}
\hline $15-18$ & 6 \\
$19-25$ & 48 \\
$26-29$ & 35 \\
$30-39$ & 21 \\
$40-49$ & 8 \\
50 i więcej & 4
\end{tabular}

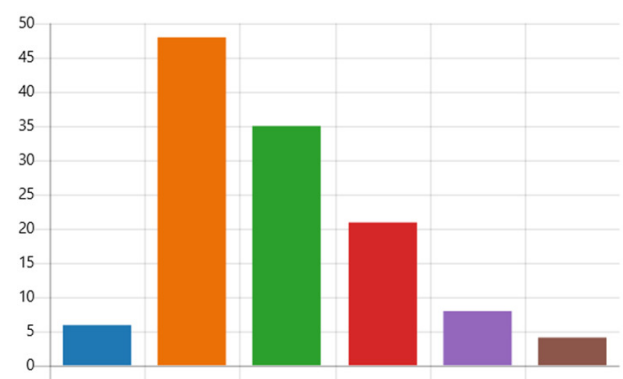

Rysunek 7. Wyniki badania - wiek ankietowanych [1]

Pytanie zawarte w sekcji trzeciej zawierają trzon zapotrzebowania dla niniejszego projektu. Rysunek 8 przedstawia wyniki pytania o korzystanie przez badanych z aplikacji zdrowotnych. Wyniki są do siebie bardzo zbliżone, z czego można wywnioskować, iż jest potrzeba stworzenia aplikacji intuicyjnej przy dobraniu odpowiednych funkcji, by skłonić połowę ankietowanych do rozpoczęcia korzystanie $\mathrm{z}$ aplikacji zdrowotnych na smartfonach w celu monitorowanie swojego zdrowia. Ponad to, w pytaniu dotyczącym o korzystane funkcje sporą przewagą odznaczają się: kalendarz, system alertów, możliwość tworzenia notatek oraz pomiar aktywności fizycznej (Rysunek 9).

5. Czy korzystasz z dedykowanych aplikacji zdrowotnych? Więcej szczegółó

$\begin{array}{ll}\text { Tak } & 72 \\ \text { Nie } & 50\end{array}$

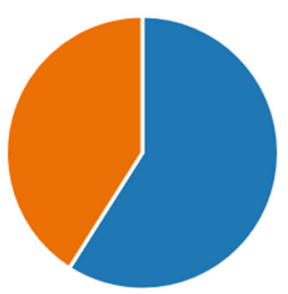

Rysunek 8. Wyniki badania - użytkowanie aplikacji zdrowotnych [1] 
6. Z jakich funkcji aplikacji byś korzystał/a? Więcej szczegótów

\begin{tabular}{lc}
\hline Kalendarz & 93 \\
System alertów & 94 \\
\hline Skrót danych z aplikacji w for... & 37 \\
\hline Notatki & 80 \\
\hline Plansza z wykresami & 23 \\
Panel logowania & 17 \\
\hline Możliwość edycji danych profilu & 15 \\
\hline Pomiar aktywności fizycznej & 84 \\
\hline
\end{tabular}

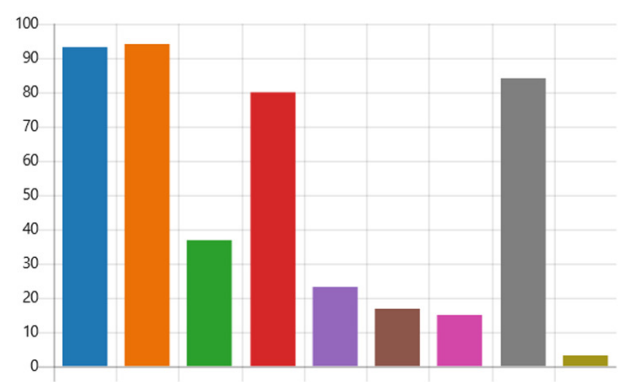

Rysunek 9. Wyniki badania - potrzebne funkcje w aplikacji mobilnej [1]

Dalsza część badania zawierająca pytania dotyczące inteligentnego zegarka pokazuje, iż aż 84\% badanych chciałoby korzystać z dodatkowych funkcjonalności (Rysunek 10). Analizując odpowiedzi pytania numer 8 można dostrzec, że dane funkcjonalności znajdujące się w aplikacji mobilnej oraz smartwatchu powtarzają się. Pozwala to na uzyskanie pełnego zapotrzebowania na wygląd oraz funkcjonalność aplikacji (Rysunek 11).

7. Czy korzystałbyś/abyś z dodatkowych funkcji aplikacji w zegarku? Więcej szczegótón

Tak

Nie

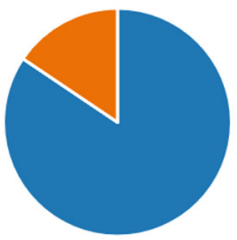

Rysunek 10. Wyniki badania - zapotrzebowania na funkcję w smartwatchu [1]

8. Jeśli tak, to z jakich?

Więcejszczegółów

Plansza z wykresami

Pomiar aktywności sportowej

Powiadomienia

Kalendarz

System alertów

Inne

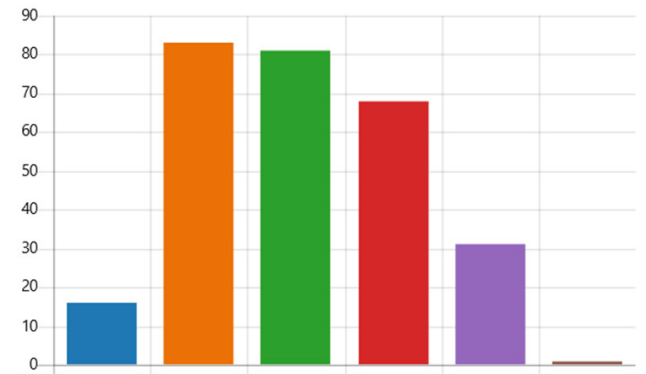

Rysunek 11. Wyniki badania - potrzebna funkcjonalność inteligentnego zegarka [1] 
Ostatnia część dotyczyła dodatkowej wypowiedzi ogólnej wśród badanych na temat całości projektu oraz sposobie korzystania z niej (Rysunek 12). W poniższych odpowiedziach widać pozytywny odbiór aplikacji, a większość ankietowanych korzystałaby z niej na początku w sposób anonimowy (Rysunek 13). Uwzględniając odpowiedzi w celu sprawdzenia przyjęcia projektu na rynku w początkowej fazie można pominąć funkcjonalność panelu logowania oraz rejestracji z uwzględnieniem zaimplementowania w kolejnych etapach.

9. Co sądzisz o takiej aplikacji? Czy taka aplikacji i zebrane z niej dane pomogły by w wcześniejszym wykrywaniu ataków epilepsji?

Więcejszczegółów

46

Najnowsze odpowiedzi

Odpowiedzi

"Myślę, że tak."

Rysunek 12. Wyniki badania - opinia ogólna ankietowanych [1]

10. Korzystałbyś/abyś z aplikacji jako użytkownik anonimy czy jawny (wiek, masa ciała, wzrost, imię, nazwisko)

Więcej szczegółón î Insights

anonimowy

jawny

85

36

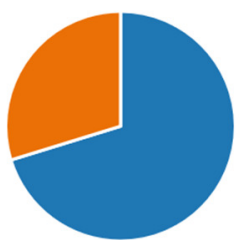

Rysunek 13. Wyniki badania - sposób korzystania z aplikacji [1]

Analizując całość otrzymanych odpowiedzi od badanych obecnie występuje zapotrzebowanie na tego typu aplikację. Należy zwrócić szczególną uwagę na funkcjonalności takie jak: system alertów, kalendarz, pomiar aktywności fizycznej oraz możliwość tworzenia notatek. Należy uwzględnić również anonimowość użytkowników podczas korzystanie z danych funkcjonalności.

\section{Epilepsja}

\subsection{Definicje}

Przy epilepsji wyróżniamy trzy główne definicje:

- Padaczka - grupa przewlekłych zaburzeń neurologicznych o różnym źródle pochodzenia, które cechuja napady padaczkowe. To zespół objawów psychicznych, wegetatywnych oraz somatycznych, które w niektórych przypadkach mogą prowadzić do obniżenia sprawności intelektualnej [3], [5], [6].

- Napad padaczkowy - to skutek nagłych, gwałtownych wyładowań bioelektrycznych w danym obszarze mózgu. Może przyjmować różne formy 
z racji występowania aż 40 postaci. Dzieli się na napady uogólnione, ogniskowe (częściowe) oraz o nieznanym początku [2], [4], [10].

- Zespół padaczkowy - to zaburzenie o podłożu padaczkowym, na podstawę której składają się: przedział wiekowy, obraz kliniczny najczęściej występujący pod postacią wyniku zmian w badaniu EEG, choroby współistniejące oraz dane objawy z nimi związane i sposób leczenia [8], [9].

\subsection{Diagnostyka}

Diagnostyka epilepsji to proces długotrwały, który odbywa się w kilku etapach. Przy nieprawidłowym funkcjonowaniu organizmu np. poprzez występujące napady padaczkowe można uzyskać skierowanie na odpowiednie leczenie. Pierwszym etapem jest szczegółowy wywiad z pacjentem, a następnie wykonuje się dodatkowe badania takie jak elektroencefalografia (EEG). Jest to rutynowy zapis czynności bioelektrycznej mózgu, który pozwala na uchwycenie stanu padaczkowego. Chcąc wykryć zmiany ogniskowe w mózgu, które mogłyby wskazywać na padaczkę lekooporną kwalifikującą się do operacji stosuje się dwa badania obrazowe [10], [12]:

- Tomografia komputerowa (TK) - umożliwia badanie warstw danego narządu. W celu zwiększenia efektywności wykonuje się tak zwane TK z podanym dożylnie kontrastem. Ze względu na mniejszą skuteczność tomografii niż rezonansu magnetycznego, TK wykonuje się w przypadku już istniejących przeciwskazaniach do jego wykonania np. podczas obecności metalowych elementów w ciele pacjenta [11], [13].

- Rezonans magnetyczny (MRI) - to badanie wykonywane w celu poszukiwania nieprawidłowości strukturalnych takich jak guzy, czy malformacje naczyniowe. W przypadku zmiany formy napadów lub pogorszenia się stanu neurologicznego pacjenta badanie należy powtórzyć. Pozwala na wykrycie zmian, których nie da się zobrazować w badaniu TK [8], [11].

Od wielu lat w leczeniu padaczki stosuje się monoterapię tj. podawanie jednego leku. Przy jego wyborze lekarz kieruje się występującymi konkretnymi objawami u pacjenta. Stosując równe odstępy czasu podwyższa się dawkę leku, aż osiągnie ona optymalną wartość w organizmie, co będzie skutkowało ustąpieniem napadów. Obecnie większość stosowanych leków daje wiele skutków niepożądanych, dlatego w tym celu stara się stosować jak najnowocześniejsze leki. Padaczka jest chorobą nieuleczalną, dlatego w celu poprawy stanu fizycznego i psychicznego sugeruje się pacjentom stosowanie zdrowego trybu życia oraz różnorakiej aktywności fizycznej [14]. [15], [16].

\section{Elektrokardiograf}

\section{1. Definicja}

„Elektrokardiogram (EKG) jest graficzna prezentacją aktywności elektrycznej serca, rejestrowanej z powierzchni ciata za pomoca elektrokardiografu. Standardowe badanie EKG obejmuje zapis potencjałów elektrycznych z 12 odprowadzeń, w tym z 3 odprowadzeń kończynowych dwubiegunowych, 3 odprowadzeń 
kończynowych jednobiegunowych oraz 6 odprowadzeń przedsercowych jednobiegunowych" [17].

Wynik uzyskujemy poprzez różnicę napięć między dwoma elektrodami, który następnie zapisywany jest na papierze EKG.

\section{2. Fizyczne podstawy elektrokardiografii}

Fizyczną podstawą elektrokardiografii są 3 założenia stworzone przez Einthovena do oceny pola elektrycznego wytwarzanego przez serce:

- Serce, tak jak dipol tworzy najprostszy generator energii elektrycznej;

- Serce znajduje się w środku geometrycznym tkanek, gdzie panują identyczne warunki przewodzenia prądu;

- Punkty połączeń lewej kończyny dolnej oraz obu kończyn górnych z tułowiem tworzą wierzchołki trójkąta równobocznego, w środku, którego znajduje się serce.

Takowy układ odprowadzeni nazywa się trójkątem Einthovena, gdzie wierzchołki oznacza się jako (R, L, F) i obrazuje on układ trzech dwubiegunowych odprowadzeń kończynowych (V1, V2, V3) [18], [19].

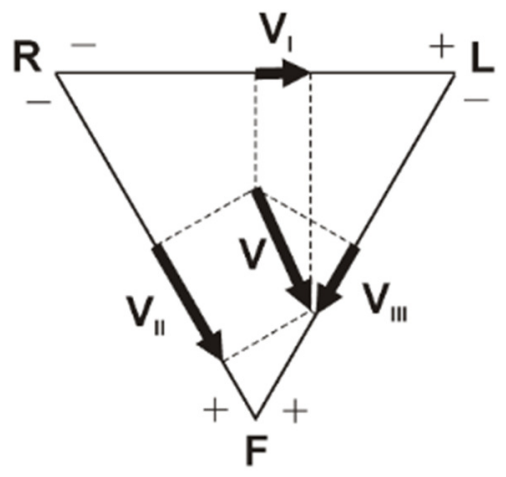

Rysunek 14. Odprowadzenia kończynowe dwubiegunowe (wedtug teorii Einthovena) [20]

Galwanometr jest ważną częścią każdego elektrokardiografu. Dzięki połączeniu $\mathrm{z}$ elektrodami znajdującymi się $\mathrm{w}$ dwóch punktach na powierzchni ciała stanowi obwód elektryczny zwany odprowadzeniem. Płynący prąd z napięcia wyższego do niższego powoduje wychylenie wskazówki galwanometru, co następnie zostaje zarejestrowane w postaci graficznej.

\section{1.2. Elektrofizjologiczna podstawa EKG}

Elektrofizjologiczna podstawa EKG wynika ze zmian potencjałów w trakcie dwóch faz: depolaryzacji i repolaryzacji mięśnia sercowego. Dzięki tym zjawiskom komórki mięśniowe kurczą się, zaś komórki nerwowe są w stanie przewodzić bodźce. 


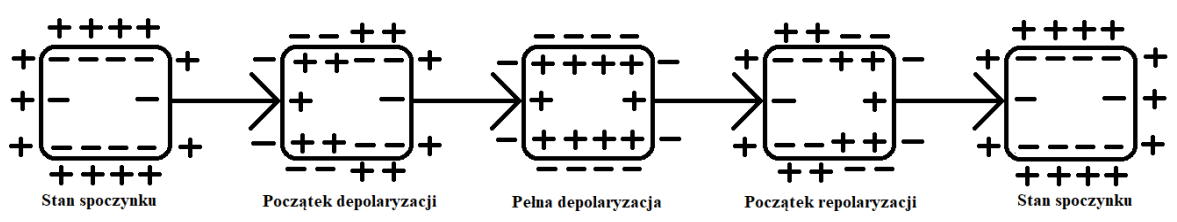

Rysunek 15. Przebieg procesu depolaryzacji i repolaryzacji [21]

\subsubsection{Potencjał spoczynkowy}

Moment polaryzacji komórek mięśnia sercowego nazywa się potencjałem spoczynkowym. Utrzymuje się wtedy prawidłowe napięcie po obu stronach błony komórkowej. Charakterystyką wartości spoczynkowych są wartości ujemne, a potencjał spoczynkowy wyróżnia:

Elektroujemność wynosząca ok. $-90 \mathrm{mV}$ we wnętrzu komórki, która jest zależna od przewagi anionów (jonów o ujemnym potencjale) od kationów (jonów o dodatnim potencjale), głównie potasu.

Błona komórkowa nie przepuszcza jonów sodu wewnątrz komórki, a przepuszcza jony potasu;

Pompa jonowa, której zadaniem jest utrzymywanie różnicy potencjałów pomiędzy wnętrzem kości, a przestrzenią międzykomórkową [22], [23].

\subsubsection{Potencjał czynnościowy}

Bodziec działający na spolaryzowaną komórkę mięśnia sercowego jest nazywany potencjałem czynnościowym. Do jego zadań należy zmiana przepuszczalności błony dla jonów sodu, które poprzez dostanie się do wnętrza komórki zmniejszają ujemny potencjał do wartości ok. $-65 \mathrm{mV}$. Na wskutek tego następuje depolaryzacja całkowita. Następstwo tego wyróżnia pięć faz:

- Faza 0 (szybka depolaryzacja) - jest zależna od szybkiego dokomórkowego prądu sodowego;

- Faza 1 (wstępna szybka repolaryzacja) - dośrodkowy prąd chlorkowy oraz odśrodkowy prąd potasowy;

- Faza 2 (powolna repolaryzacja) - charakteryzuje ją stabilizacja potencjału i równowaga między odśrodkowym prądem potasowym, a dośrodkowym prądem wapniowym;

- Faza 3 (szybka repolaryzacja) - następuje przewaga odśrodkowego prądu potasowego nad zmniejszającym się dośrodkowym prądem wapniowosodowym;

- $\quad$ Faza 4 (polaryzacja) - faza spoczynku.

Dzięki temu, że wszystkie fazy charakteryzują się innym przepływem jonów, to pobudzenie elektryczne serca nadąża za pobudzeniem odpowiednich komórek mięśniowych. Jednocześnie podczas trwającej w tym samym czasie depolaryzacji nie może dojść do następnego pobudzenia, co mogłoby powodować zaburzenia pracy serca [23], [24]. 


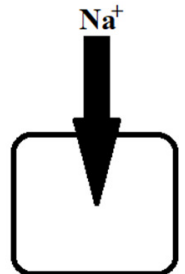

Faza 0

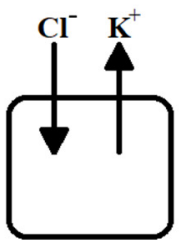

Faza 1

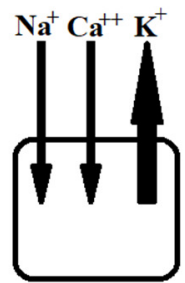

Faza 2

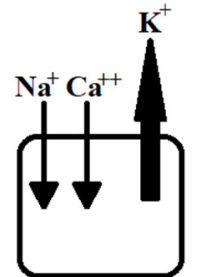

Faza 3

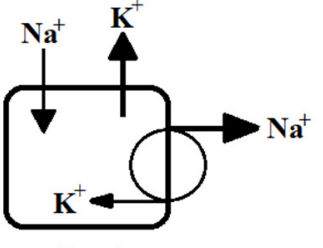

Faza 4

Rysunek 16. Zmiany jonowe zachodzace podczas potencjału czynnościowego [25]

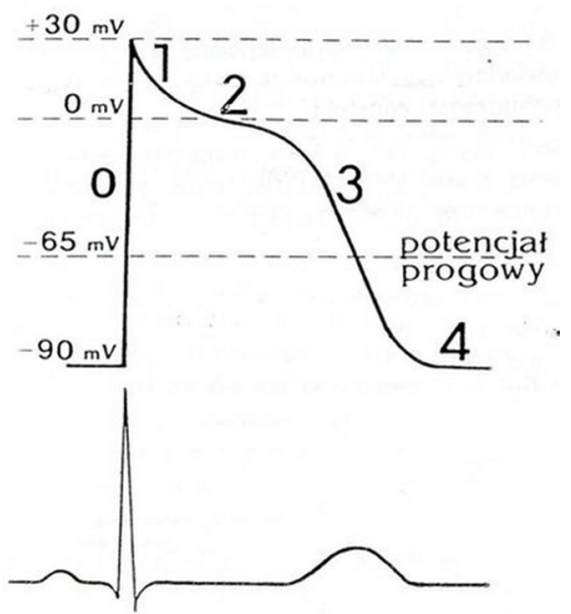

Rysunek 17. Składowe elektrokardiogramu w danych fazach potencjału iglicowego [26]

\subsection{Charakterystyka rutynowego badania EKG}

Serce generuje potencjały elektryczne odbierane za pomocą odprowadzeń, które dzieli się na:

- Odprowadzenia jednobiegunowe - elektroda badająca potencjał jest dodatnia, a następnie zostaje umieszczona w miejscu pomiaru. Druga elektroda jest obojętna, i jej napięcie jest równe zero. Odprowadzenie to mierzy więc bezwzględny potencjał w jednym punkcie badanego pola elektrycznego;

- Odprowadzenia dwubiegunowe - elektrody zostają umieszczone w punktach z różnym potencjałem oraz rejestrują one różnice potencjałów między dwoma punktami.

Klasyczny elektrokardiogram obejmuje dwanaście odprowadzeni elektrycznych stosowanych podczas badania: trzy odprowadzenia kończynowe dwubiegunowe, trzy odprowadzenia kończynowe jednobiegunowe, sześć odprowadzeń przedsercowych jednobiegunowych.

Podział odprowadzeń kończyn dwubiegunowych: 
- Odprowadzenie I - rejestruje różnicę potencjałów pomiędzy: lewym przedramieniem $(+)$, a prawym przedramieniem $(-)$;

- Odprowadzenie II - rejestruje różnicę potencjałów pomiędzy: lewym podudziem $(-)$, a prawym przedramieniem $(+)$;

- Odprowadzenie III - rejestruje różnicę potencjałów pomiędzy: lewym podudziem (+), a lewym przedramieniem (-) [19], [24].

।

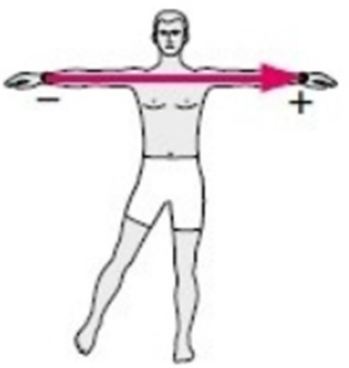

II

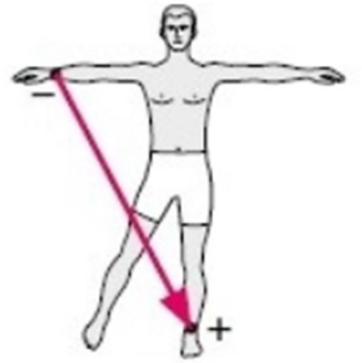

III

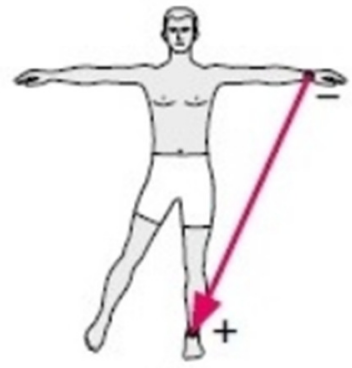

Rysunek 18. Odprowadzenia kończynowe dwubiegunowe [27]

Przy odprowadzeniach kończynowych jednobiegunowych elektrodę dodatnią umieszcza się na jednej z kończyn, natomiast elektroda obojętna stanowi połączenie elektrod z dwóch kończyn i jest to zwane modyfikacją Goldberga. Konstrukcję współczesnych elektrokardiografów zapewnia tworzenie elektrody obojętnej. W powyższej modyfikacji odprowadzenia te oznacza się jako:

- Odprowadzenie $\alpha \mathrm{VL}$ - z lewej kończyny górnej;

- Odprowadzenie $\alpha \mathrm{VF}$ - z lewej kończyny dolnej;

- Odprowadzenie $\alpha \mathrm{VR}$ - z prawej kończyny górnej.
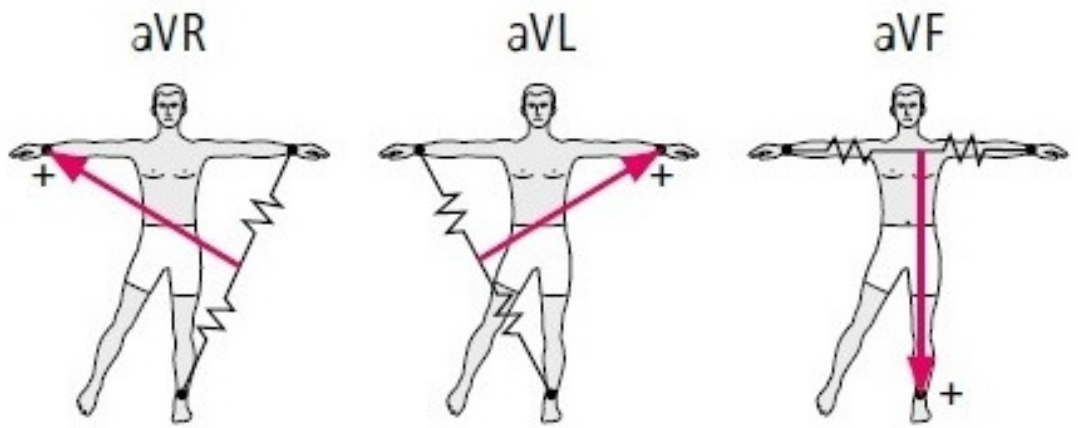

Rysunek 19. Odprowadzenia kończynowe jednobiegunowe [27]

Rejestrowanie bezwzględnej wartości potencjału w punktach, które znajdują się na klatce piersiowej należy do odprowadzeń jednobiegunowych przedsercowych. Spięte 
przewody z trzech odprowadzeń kończynowych stanowią elektrodę obojętną zwaną elektrodą Wilsona. Dodatnia elektroda badająca zostaje umieszczona w sześciu punktach klatki piersiowej:

- $\quad$ Odprowadzenie V1 - znajduje się w IV międzyżebrzu przy prawym boku mostka;

- Odprowadzenie V2 - znajduje się w IV międzyżebrzu przy lewym brzegu mostka;

- Odprowadzenie V3 - znajduje się w połowie odległości między odprowadzeniami V2 i V4;

- Odprowadzenie V4 - znajduje się w prawym międzyżebrzu i przecina je linia środkowo - obojczykowa lewa;

- Odprowadzenie V5 - znajduje się na poziomie V4 w linii pachowej przedniej lewej;

- Odprowadzenie V6 - znajduje się na poziomie V4 w linii pachowej środkowej lewej.

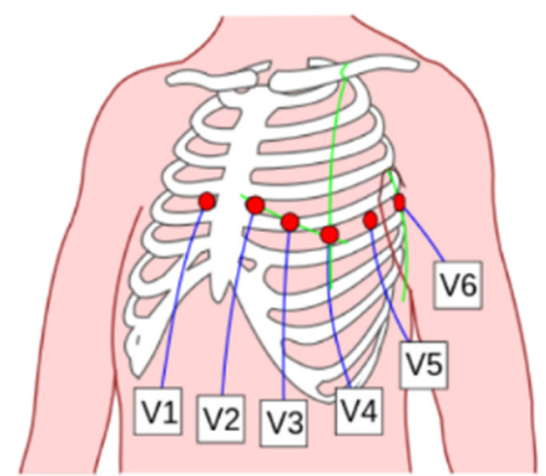

Rysunek 20. Odprowadzenia przedsercowe [28]

W większościach przypadków powyższy schemat badania EKG powinien wystarczyć do ustalenia rozpoznania elektrokardiograficznego. W przeciwnym wypadku można wykorzystać odprowadzenia dodatkowe. Badanie elektrokardiografem nie jest niezawodnym kryterium w celu rozpoznania danej choroby. Istnieje możliwość wystąpienia błędnego zapisu czynności elektrycznej przy prawidłowym stanie zdrowia pacjenta oraz poprawnie klinicznego elektrokardiogramu przy występujących schorzeniach kardiologicznych.

Analizując wykres EKG można wyróżnić cztery charakterystyczne składowe:

- Odstępy - części krzywej EKG, które obejmują łączny czas trwania odcinków i załamków;

- Odcinki - czas trwania linii izoelektrycznej pomiędzy załamkami;

○ Załamki - to wychylenia w górę lub w dół od linii podstawowej zapisu EKG. Umownie oznacza się je literami: P, Q, R, S, T i U:

○ Załamek P - związany jest z depolaryzacją przedsionków;

○ Załamek T - repolaryzacja komór;

○ Zespół załamków QRS - depolaryzacja komór; 
○ Załamek U - jest niewyjaśniony, występuję w ok. 25\% wszystkich zapisów EKG;

- Linie izoelektryczne - linie poziome zarejestrowane w czasie, gdy w sercu nie stwierdza się żadnej aktywności. Względem nich określa się przemieszczenia odcinków oraz amplitudę załamków. Wyznacza się je według odcinka PQ, TP lub według linii łączącej punkty początkowe sąsiadujących zespołów QRS.

Przedsionkowa część elektrokardiogramu jest złożona z odcinka PQ oraz załamka P, natomiast część komorowa składa się z zespołu QRS, załamka T i odcinka ST [22], [23], [24].

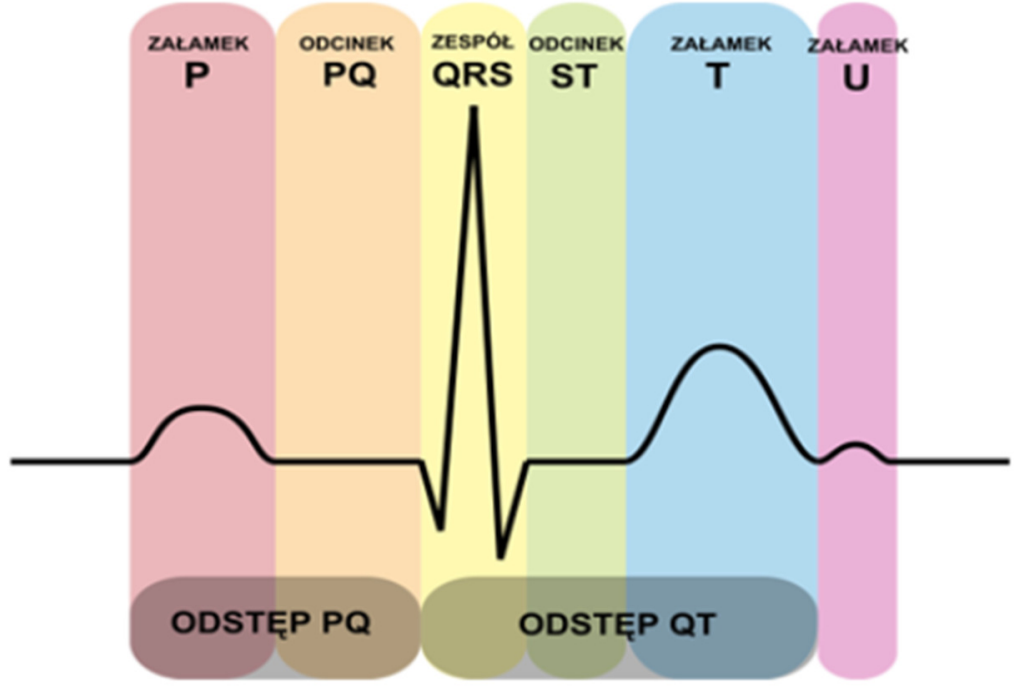

Rysunek 21.Schemat przebiegu EKG [29]

\section{Podsumowanie}

Celem projektu było sprawdzenie zapotrzebowania wdrożenia aplikacji mobilnej mierzącej parametry medyczne dla epileptyków. Przeprowadzone badanie rynku dostarczyło odpowiednie wnioski dotyczące funkcjonalności przyszłej aplikacji. Dzięki miniaturyzacji elektroniki obecnie akcesoria typu smartwatch wspomagają użytkowników podczas diagnostyki zdrowia oraz treningów. Czujniki zawarte w inteligentnych zegarkach umożliwiają pomiar m.in. natlenienia krwi oraz wykonać elektrokardiografię serca. Wykorzystując zebrane informację będzie można stworzyć aplikację, która wspomoże ludzi w diagnostyce chorób przewlekłych oraz codziennych aktywnościach fizycznych. 


\section{LITERATURA}

1. JANIK J.: Aplikacja mobilna mierząca parametry medyczne dla epileptyków, Akademia Techniczno-Humanistyczna, inż., Praca inżynierska numer 659/KliA Bielsko-Biała, 2021.

2. Serwis: https://forms.office.com/Pages/ResponsePage.aspx?id=H6rbcLNVZOqWOXun DWf2uUnw9NmLXllBk89Ikjdg115UNTEySORWM1c2RDY4QUtZMEpRWUwy TllJRC4u\&fbclid=IwAR21ejfVuDDVSf32Pyd7SOQImho_uK3cLr72ywgg_T1G 578fQzB_cTABgqM

3. CARPE T., CARTER N., ROGERS A.: Mastering Office 365 Administration, Packt Publishing, May 2018.

4. FISHER RS, VAN EMIE BOAS W, BLUME W, et al.: Epileptic seizures and epilepsy: definitions proposed by International League against epilepsy (ILAE) and the International Bureau for Epilepsy (IBE). Epilepsy 2005;46(4):470-472.

5. Atlas: Epilepsy care in the world. Geneva, Switzerland: World Health Organization; 2005. World Health Organization

6. Oddział Neurologii Dziecięcej Wojewódzki Specjalistyczny Szpital Dziecięcy w Olsztynie, Padaczka - najczęstsza przewlekła choroba układu nerwowego u dzieci, https://wl.uwm.edu.pl/sites/default/files/download/ 201801/padaczka-studenci_-_dr_morski.pdf, data dostępu 06.06.2021r.

7. ROZENEK H., OWCZARZAK K.: Warunki funkcjonowania chorych na padaczkę wpływające na jakość życia, Neurologia po Dyplomie 2010; 5 (6): 37-43.

8. PITTAU F., KORFF C.M., NORDLI D.R. JR.: Epileptic spasms in epilepsy with myoclonic-atonic seizures (Doose syndrome). Epileptic Disord. 2016; 18(3): 289-96.

9. ŁUKAWSKA M., SARAMAK K., SŁOWIŃSKA M., Padaczka charakterystyka oraz metody leczenia, Warszawa 2016, https://sknnd.wum.edu.pl/sites/sknnd.wum.edu.pl/files/padaczka-charakterystyk a_oraz_metody_leczenia_-_konspekt_21.05.pdf, s. 1-8, data dostępu: 26.06.2021.

10. MAKOWSKI J., RYGLEWICZ D., STELMASIAK Z.: Sesja 6. Zespoły padaczkowe, Polski Przegląd Neurologiczny, 2010, tom 6, supl. A.

11. ŁUKAWSKA M., SARAMAK K., SŁOWIŃSKA M.: Konferencja Warszawskiej Akademii Pediatrii: Padaczka - czy można jej zapobiec? O najnowszych osiągnięciach w dziedzinie epileptologii metodach leczenia, 21.05.2016, Warszawa.

12. REJDAK K., ROLA R., MAZURKIEWICZ-BEŁDZIŃSKA M., HALCZUK I., BŁASZCZYK B.,. RYSZ A, RYGLEWICZ D.: Diagnostyka i leczenie padaczki u osób dorosłych - rekomendacje Polskiego Towarzystwa Neurologicznego, Polski Przegląd Neurologiczny 2016; 12 (1): 15-27.

13. KRUMHOLZ A., et al.: Practice Parameter: Evaluating an apparent unprovoked first seizure in adults (an evidencebased review), Neurology 2007.

14. LOWENSTEIN D.: Seizures and Epilepsy w Harrison's Neurology in Clinical Medicine, McGraw-Hill 2013. 
15. NIEDZIELSKA K., BARAŃSKA-GIERUSZCZAK M.: Leczenie padaczki, Zakład Neurofizjologii Klinicznej i II Klinika Neurologiczna, Instytut Psychiatrii i Neurologii w Warszawie.

16. HELIER A.: Phenobarbitone, phenytoill, carbamazepine ar sodium valproate for newly diag-nosed adult epilepsy: a randomised comparative monotherapy trial. J. Neuro!. Neurosurg. Psychiatry 1995, 58, 44.

17. RICHENS A., PERUCCA E.: Clillical pharmacology and medical treatmellt. W.: A Textbook Dr Epilepsy, 4th edition. Laidlaw i wsp. (red.), Churchill Livingstone, London 1993,495.

18. Praca zbiorowa (2017) Interna Szczeklika 2017, pod red. Piotra Gajewskiego, Medycyna Praktyczna, Kraków 2017.

19. TOMASIK T., WINDAK A., SKALSKA A., KULCZYCKA ŻYCZKOWSKA J. , KOCEMBA J.: Elektrokardiografia dla lekarza praktyka, Uniwersyteckie Wydawnictwo Medyczne „Vesralius”, Kraków 1998.

20. TRACZYK W. Z.: Fizjologia człowieka w zarysie, wydaw. PZWL, wyd. VIII - 11 dodruk, ISBN 978-83-200-4655-7, Warszawa 2016

21. Serwis internetowy: http://www.biofiz.umed.wroc.pl

22. Serwis internetowy: http://home.agh.edu.pl/ asior/stud/doc/EKG\%20Uklad\%2 Okrazenia.pdf

23. TOMASIK T., WINDAK A., SKALSKA A., KULCZYCKA ŻYCZKOWSKA J., KOCEMBA J.: Elektrokardiografia dla lekarza praktyka, Uniwersyteckie Wydawnictwo Medyczne „Vesralius”, Kraków 1998.

24. KONTUREK S.: Fizjologia człowieka, Tom IV, Wydawnictwo Urban\&Partner, Wrocław 2014.

25. Katedra Fizyki i Biofizyki UWM, Przewodnik do ćwiczeń laboratoryjnych z biofizyki dla Wydziału Nauk Medycznych Monika Pietrzak, Grażyna Ibron, Zbigniew Wieczorek, Aktywność elektryczna serca. Elektrokardiografia, 2011.

26. Serwis internetowy: http://home.agh.edu.pl/ asior/stud/doc/EKG\%20Uklad\%2 Okrazenia.pdf

27. Serwis internetowy: http://home.agh.edu.pl/ asior/stud/doc/EKG\%20Uklad\%2 Okrazenia.pdf

28. Serwis internetowy: http://www.ratownikmed.pl/czynnosci/czynnosci_monitoro wanie.html

29. Serwis internetowy: https://www.wikiwand.com/pl/Elektrokardiografia

30. Serwis internetowy: http://www.cs.put.poznan.pl/mkadzinski/diviz/inz/BScAGJ T.pdf 
